Balke, T. and Nilsson, C. (2019) Increasing synchrony of annual riverflood peaks and growing season in Europe. Geophysical Research Letters, 46(17-18), pp. 446-453.

There may be differences between this version and the published version. You are advised to consult the publisher's version if you wish to cite from it.

This is the peer reviewed version of the following article:

Balke, T. and Nilsson, C. (2019) Increasing synchrony of annual riverflood peaks and growing season in Europe. Geophysical Research Letters, 46(17-18), pp. 446-453. (doi: 10.1029/2019GL084612)

This article may be used for non-commercial purposes in accordance with Wiley Terms and Conditions for Self-Archiving.

\title{
http://eprints.gla.ac.uk/193975/
}

Deposited on: 02 September 2019

Enlighten - Research publications by members of the University of Glasgow http://eprints.gla.ac.uk/ 
Balke Thorsten (Orcid ID: 0000-0001-7733-5069)

\section{Increasing Synchrony of Annual River-Flood Peaks and Growing Season in Europe}

\section{Thorsten Balke ${ }^{1}$ and Christer Nilsson ${ }^{2,3}$}

${ }^{1}$ School of Geographical and Earth Sciences, University of Glasgow, Glasgow, UK

${ }^{2}$ Department of Ecology and Environmental Science, Umeå University, Umeå, Sweden

${ }^{3}$ Department of Wildlife, Fish and Environmental Studies, Swedish University of Agricultural Sciences, Umeå, Sweden

Corresponding author: Thorsten Balke (thorsten.balke@ glasgow.ac.uk)

\section{Key Points:}

- Annual river-flood peaking increasingly occurs within the thermal growing season in Central and Eastern Europe since the 1960s

- Spring advance and flood-peak delay both contribute to increasing synchrony of flood peaking and growing season

- We discuss the potential consequences of increased synchrony such as higher hydraulic roughness and disturbance to seedling establishment

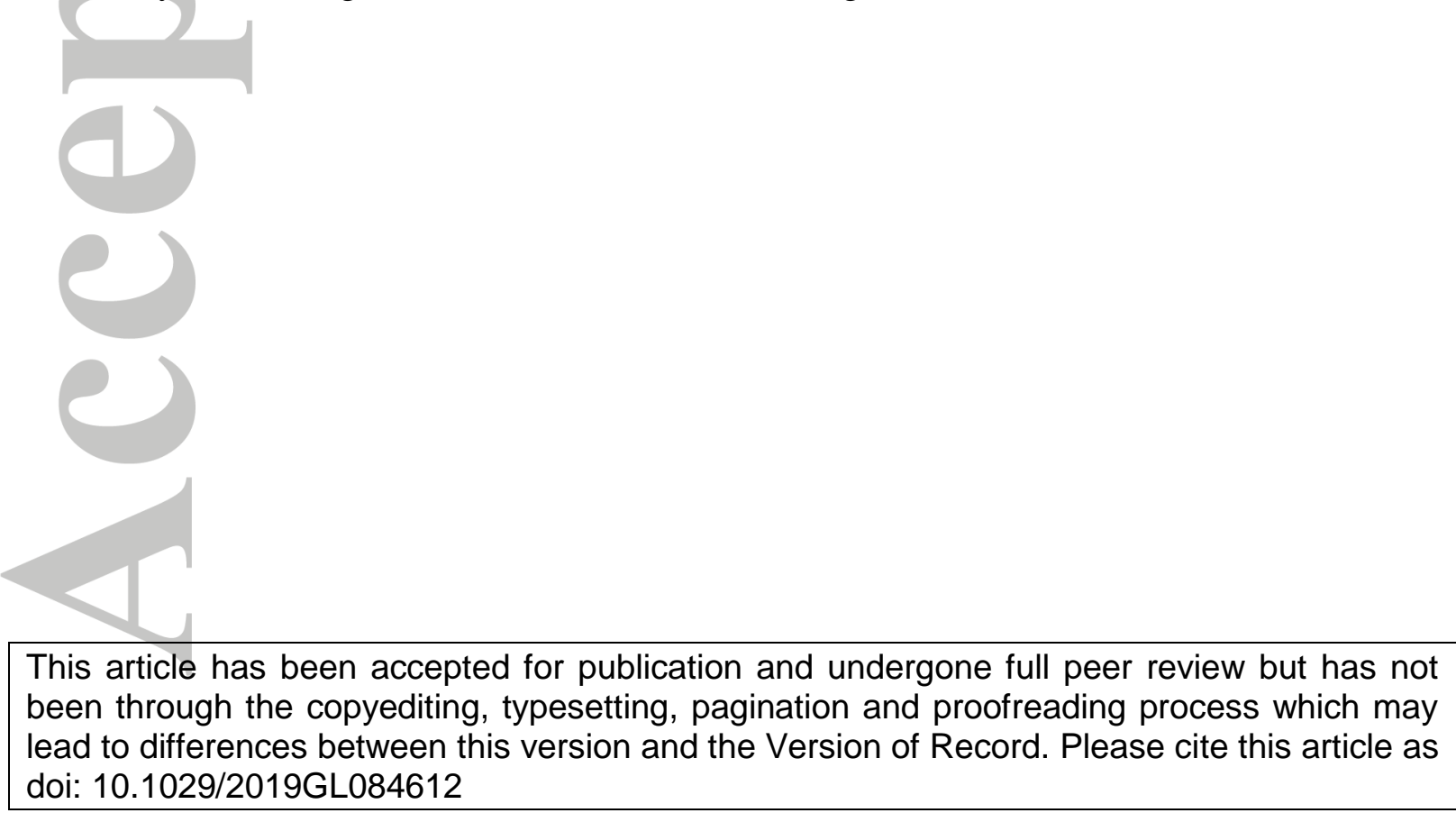




\begin{abstract}
In a changing climate, time sensitive ecological interactions such as pollination and predation are vulnerable to temporal mismatch with direct consequences for ecosystem functioning. It is not known if synchrony and asynchrony of ecological and physical processes such as flood disturbance and plant phenology may similarly be affected by climate change. Here, by spatially merging temperature and flood peak data, we show for the first time that in Central and Eastern Europe annual river flood peaks increasingly occur within the thermal growing season. This is due to the combined effect of earlier springs and later flood peaks. Such increased physical-phenological synchrony may especially impact river biogeomorphology and riparian floodplain ecosystem functioning through uprooting of seedlings and increased hydraulic roughness during major flood events.
\end{abstract}

\title{
Plain Language Summary
}

Life history events of organisms, such as the spring emergence of certain plant species or the onset of migration of animals, are determined by seasonal weather patterns (for example spring temperatures). Where river flooding potentially disrupts the development and movement of plants and animals in the floodplain, the timing of both the organism's behavior and the flood events become crucial. Our study shows that the timing of the biologically active growing season has changed in relation to the timing of annual river flood peaks in Europe since the 1960s. In Central and Eastern Europe especially flood peaks are generally occurring later, and the yearly growing seasons start earlier in spring. This has currently unknown consequences for the river and floodplain ecosystems but is likely to change the way river hydrology, plants and sediments interact. We encourage further studies to investigate the effects of altered seasonal synchrony between physical (e.g., flooding) and ecological landscape processes. 


\section{Introduction}

Global climate change advances or delays the timing of life cycle events (i.e., phenology) differently across species. This changes the temporal match/mismatch of ecological interactions with likely consequences for ecosystem functioning (Parmesan \& Yohe, 2003; Seddon et al., 2016; Thackeray et al., 2016; Visser \& Gienapp, 2019). Trophic mismatch, for example, occurs where consumers become desynchronized from their resource production (e.g., nectar and pollinating insects, plankton and fish or insect prey and migratory birds) and this affects the entire trophic cascade (Edwards \& Richardson, 2004) as well as biodiversity (Stevenson et al., 2015).

While consumers profit from temporal matching of their most energy-expensive period (e.g., during reproduction) with peak availability of their resources (Cushing, 1990), vascular plants in frequently flooded ecosystems benefit from synchrony of their most sensitive establishment phase with periods of low or absent physical disturbance (e.g., flooding), so called 'Windows of Opportunity' (WoO) (Balke, Herman \& Bouma, 2014). Extreme floods are a main driver to the structure and functioning of riparian floodplain vegetation and biogeomorphology (Friedman \& Lee, 2002). Similarly, the timing and duration of floods are important for animal recruitment, for example fish (King et al., 2003; Pusey \& Arthington, 2003), birds (Royan et al., 2013), nest-building vertebrates (Mainwaring et al., 2017), and insects, such as mosquitoes (Sang et al., 2017). The effects of gradual warming vs. short-term heat pulses (Inouye, 2008; Jentsch et al., 2009), physical disturbance (Miller et al., 2010; Balke et al., 2011) and physical drivers to diaspore dispersal and deposition (Mahoney \& Rood, 1998; Nilsson et al., 2010) are well understood in riparian and coastal plant communities, yet the effects of different timings are underappreciated.

Biogeomorphic feedbacks between vegetation and sediment transport that shape riparian, salt marsh, mangrove and dune landscapes are increasingly incorporated in conceptual, physical and numerical models (e.g., for riparian vegetation: Perucca, Camporeale \& Ridolfi, 2007; Tal \& Paola, 2007; Corenblit et al., 2015). However, the drivers and potential effects of temporal synchrony/asynchrony of abiotic and biotic processes on biogeomorphic landscapes and species populations are currently unknown. This is despite the growing interest in regulating ecosystem services (i.e., flood and erosion protection) of vegetation in such systems especially during extreme storms and flood events (Möller et al., 2014).

Globally, many people rely on predictable flooding regimes in relation to the biologically active season, for example for floodplain agriculture and fisheries (Coomes et al., 2016; Isaac et al., 2016). Shifts of flood timing in relation to harvest seasons can therefore have negative socioeconomic consequences. For example, in South Louisiana, US, farmers lost crops, livestock and equipment worth at least $\$ 367$ million to floods in 2016 (McClure, 2016). Furthermore, reindeer herders depend on periods of persistent ice cover for reindeer migration (Leblond et al., 2016). If ice seasons become shorter (and floods earlier), such migration will no longer be possible (cf. Cooper, 2014).

There is substantial evidence that the physical forcing to ecosystems has been changing. In Europe storminess (i.e., magnitude and frequency) has increased towards the end of the $20^{\text {th }}$ century (Donat et al., 2011) and Northern Europe currently experiences an increase in annual precipitation of up to $70 \mathrm{~mm}$ per decade (Kovats et al., 2014). The timing of yearly river flood peaks has changed across Europe with different regions experiencing consistently earlier or later annual maximum flood peaking depending on altered weather oscillations, timing of soil-water saturation and of snow melt (Blöschl et al., 2017). Spatially, however, 
the area of annual river flood peaks occurring at the same time has increased in most of Europe (Berghuijs et al., 2019). These spatially complex changes in flood peak timing across Europe occur alongside an overall lengthening of the growing season (especially due to spring advancement, i.e., earlier start of spring) across Europe. Spring advancement has been well evidenced by in-situ phenological observations (Menzel, 2000) and analysis of bioclimatological parameters such as the thermal growing season and growing degree days (Ruosteenoja et al., 2016; Wypych et al., 2017). The ecological consequences of a more extreme and warming climate and changed timing of physical forcing at the landscape scale, however, remain speculative (Woodward et al., 2016). So far, climate-change induced shifts in timing of physical-phenological interactions and the impacts on biodiversity have not been systematically studied across ecosystems. This requires a spatially explicit continental scale analysis due to the regional differences in flood-peak timing and spring advancement.

Our study provides new insights in how recent changes in climate across Europe have potentially changed the synchrony/asynchrony of flooding patterns and ecological processes. We do this by pairing information on annual river flood peaks with temperature records between 1960 and 2010. Finally, we explore potential consequences of increased synchrony between flood peaking and thermal growing season with a particular focus on riparian vegetation and biogeomorphology.

\section{Materials and Methods}

\subsection{Datasets}

In a recent publication, Blöschl et al. (2017) presented an analysis of the timing of the annual maximum river flood peak for 4062 hydrometric stations across Europe. They filtered the data for catchments with minimal anthropogenic influence on the hydrology and for catchment areas that are larger than $5 \mathrm{~km}^{2}$ and smaller than $100,000 \mathrm{~km}^{2}$. We used these dates of all annual maximum flood peaks between 1960 and 2010 for all considered hydrometric stations from the supplementary information of Blöschl et al. (2017). Each hydrometric station contains an individual number and geographic coordinates. Weather data in form of gridded daily mean temperature across Europe were available from the E-OBS dataset of the EU-FP6 project ENSEMBLES (see Haylock et al., 2008). We retrieved the 0.5-degree regular grid Version 15.0 of the daily mean temperature for data between 1960 and 2010 from www.ecad.eu to spatially pair temperatures with the flood-peak time series.

\subsection{Time series analysis and determination of thermal growing season}

The closest temperature grid cell to each hydrometric station was determined to merge the flood-peak time series with the nearest temperature time series. The nearest grid cell to some hydrometric stations near the coast did not contain any data. In this case the next grid cell to the West and subsequently to the East were queried. We paired a total of 3982 hydrometric stations with daily averaged temperature records. Commonly used baseline temperature for plant growth in temperate climates of $\geq 5^{\circ} \mathrm{C}$ and of $\geq 10^{\circ} \mathrm{C}$ for Mediterranean climates were applied to determine the thermal growing seasons. The same baseline temperatures are generally applied to quantify heat accumulation to predict phenological events, also known as Growing Degree Days (see Ruosteenoja et al., 2016 and Wypych et al., 2017 for recent examples in the study region). The $\geq 5^{\circ} \mathrm{C}$ base temperature was shown to be required for growth of Salix species (e.g., Kopp et al., 2001) whereas warmer temperatures, between $8^{\circ} \mathrm{C}$ 
and $14^{\circ} \mathrm{C}$ were shown to be required to initiate shoot emergence in Mediterranean riparian plants such as Arundo donax (Spencer \& Ksander, 2006). The start date of the thermal growing season near each hydrometric station was defined as the first day of the first five consecutive days $\geq 5^{\circ} \mathrm{C}$ or $\geq 10^{\circ} \mathrm{C}$, respectively for each calendar year. We defined the end of the thermal growing season as the last day of the last five consecutive days $\geq 5^{\circ} \mathrm{C}$ or $\geq 10^{\circ} \mathrm{C}$ for each calendar year (see Maps S1-S6). The choice of five consecutive days above or below baseline temperatures is in line with the method applied by the Department of Energy and Climate Change (2013) to determine growing seasons in England.

We translated flood-peak occurrence into binary values with 1 if the flood peak occurred within the thermal growing season and 0 if the flood peak occurred outside the thermal growing season in each calendar year for each station. We carried out a logistic regression for the binary flood-peak occurrence data at each station to determine significant shifts between flood-peak occurrence within or outside the growing season during the study period using a binomial Generalized Linear Model (GLM). We produced a GLM for flood-peak occurrence in relation to growing season for each hydrometric station with more than $80 \%$ of years with flood-peak data (2618 stations, S7) for the period between 1960 and 2010. For the trend analysis temporal autocorrelation of the binary time series was not considered. All stations with significant trends of increasing flood peak-growing season synchrony (i.e., increasing probability of flood-peak occurrences within the growing season at $P<0.05$ significance) were further analyzed using histograms of flood-peak timing (i.e., synchrony and asynchrony with growing season per year and station) for two 25-year time windows (i.e., 1960-1984 and 1985-2009). We calculated further parameters such as the percentage of flood-peak occurrence within the growing season and average length of the thermal growing season across the time series for all stations (S8-S10). We created two-dimensional histograms to visualize the predominant flood-peak occurrences across the time series for both considered baseline temperatures. The data for all stations with significant changes in synchrony and further maps on thermal growing season lengths, standard deviation and linear trends are available in the supplementary information. $\mathrm{R}$ packages are referenced in S11.

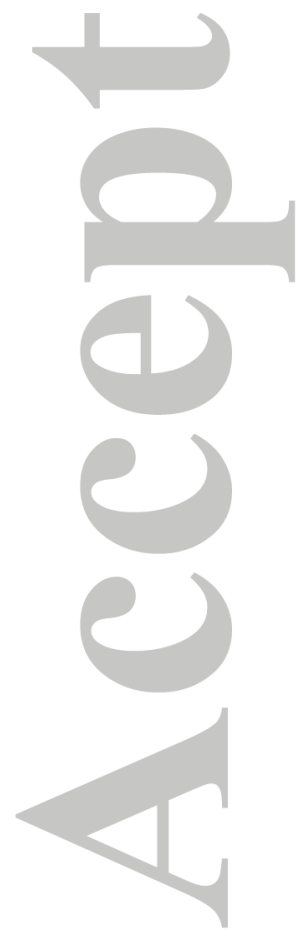




\section{Results:}

Figure 1:
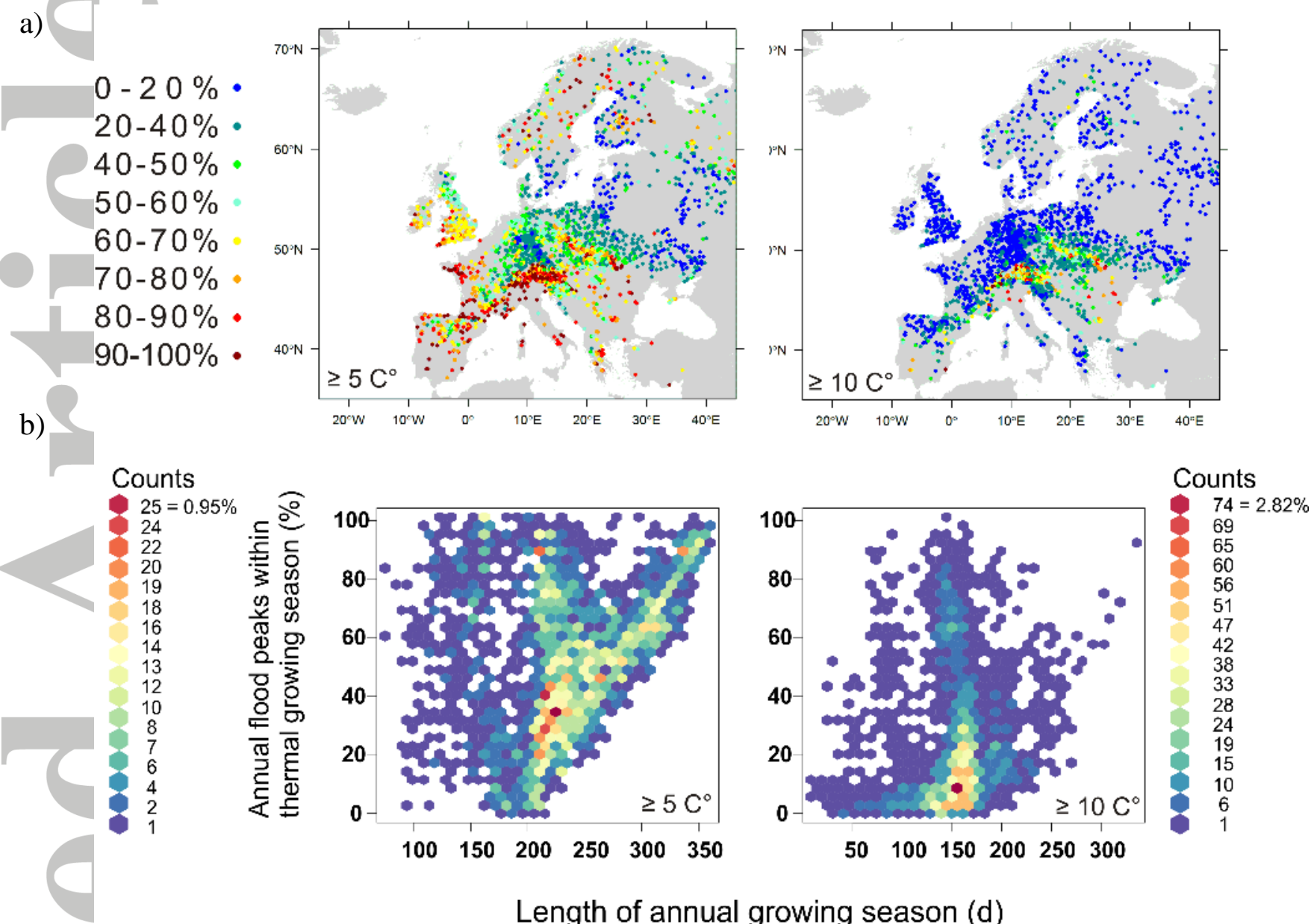

\section{Length of annual growing season (d)}

Figure 1. (a) Percentage of flood peaks occurring within the thermal growing season for each river gauge between 1960 and 2010 across Europe. Flood-peak occurrences within the $\geq 5^{\circ} \mathrm{C}$ thermal growing season are generally exceeding 60-70 \% in the Atlantic and Mediterranean biogeographic region whereas in the more continental climates of central and Eastern Europe flood-peak occurrence drops below 50-60\%. Flood-peak occurrence within the $\geq 10^{\circ} \mathrm{C}$ thermal growing season only notably exceeds $20-40 \%$ in the regions around the Alps and the Carpathian Mountains in Eastern Europe and parts of the Mediterranean region. For both figures, only river gauges with $>80 \%$ of data between 1960 and 2010 are shown $(N=2618)$. (b) Two-dimensional histograms of the average thermal growing season length $\left(\geq 5^{\circ} \mathrm{C}\right.$ and $\geq 10^{\circ} \mathrm{C}$ ) at each river gauge and the percentage of flood peaks occurring within the thermal growing season between 1960 and 2010.

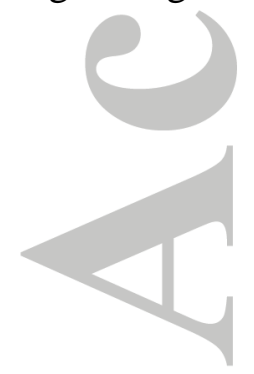


The relationship between timing of annual peak flooding and growing season varies across Europe. Depending on the region, annual flood peaks can occur predominantly within or outside of the growing season during the study period (Figure 1a). There is a general divide between river gauges North and East of the Alps where flood peaks occur predominantly outside of the $\geq 5^{\circ} \mathrm{C}$ thermal growing season (with <200-250 days durations in agreement with estimates by Wypych et al., 2017 for Poland) and South and West of the Alps where annual flood peaking occurs predominantly $(>50 \%)$ within the $\geq 5^{\circ} \mathrm{C}$ thermal growing season (with >200 days duration) (Figures 1a and S1). Not surprisingly, longer growing seasons generally increase the percentage of flood peaks occurring within the growing season (Figure 1b) and consequently river gauges with high flood-peak occurrence outside the $\geq 5^{\circ} \mathrm{C}$ thermal growing season do not exist for stations with long annual growing seasons in our dataset. The generally shorter $\geq 10^{\circ} \mathrm{C}$ thermal growing season is less likely to overlap with the annual flood peak (Figures $1 \mathrm{a}$ and $\mathrm{b}$ and S2). Synchrony of the annual flood peak with the $\geq 10^{\circ} \mathrm{C}$ thermal growing season is $<20 \%$ for large areas of Europe with exceptions in mountainous catchments where overlap is higher (Figures 1a and b).

Annual growing seasons have generally become longer in Europe as evidenced by vegetation indices and bioclimatological indicators (Jeong et al., 2011; Barichivich et al., 2013; Wypych et al., 2017). This is also shown by the significant linear increase of the length of the thermal growing season near hydrometric stations in our dataset (see S3 and S4). The logistic regression time-series analysis showed that 176 hydrometric stations experienced a significant increase in flood-peak occurrences within the $\geq 5^{\circ} \mathrm{C}$ thermal growing season (at $P<0.05,332$ stations at $P<0.1$ ) between 1960 and 2010 (see S8). The majority is located between $50^{\circ}$ and $55^{\circ}$ North in Central Europe, in an area ranging from Germany and Poland to Ukraine (Figure 2a). This increasing synchrony of flood peaking and thermal growing season is a combined effect of the delay in flood-peak occurrence in the region (sensu Blöschl et al., 2017) and the advance of the start of the thermal growing season in spring (Figure 2b). Within growing season flood peak occurrences have increased from $17.3 \%$ (1960-1969) to 62.9\% (2000-2009) (Table S10) for all stations with significant positive GLM slopes (for $\geq 5^{\circ} \mathrm{C}$, Figure $2 \mathrm{a}$. and Table S10) when comparing the first and last 10 years of the time series.

Increasing synchrony between flood peaking and $\geq 10^{\circ} \mathrm{C}$ thermal growing season (GLM results at $P<0.05$ ) was observed for 59 hydrometric stations in a narrow band from West to East (Figure 2a). This was predominantly attributed to increased occurrences of flood peaks within the summer month (Figure 2b). Within growing season flood peak occurrences have increased from $14.2 \%$ (1960-1969) to 55.8\% (2000-2009) for all stations with significant positive GLM slopes (for $\geq 10^{\circ} \mathrm{C}$, Figure $2 \mathrm{a}$ and Table S10). Twenty-five stations (for $\geq 5^{\circ} \mathrm{C}$ at $P<0.05,56$ stations at $P<0.1$ ) and 23 stations (for $\geq 10^{\circ} \mathrm{C}$ at $P<0.05$ ) showed an increasing asynchrony (i.e., occurrences outside the thermal growing season) without a clear spatial pattern (Figure 2a).

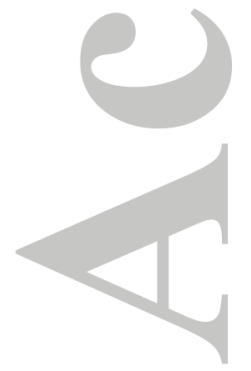




\section{Figure 2:}

a)

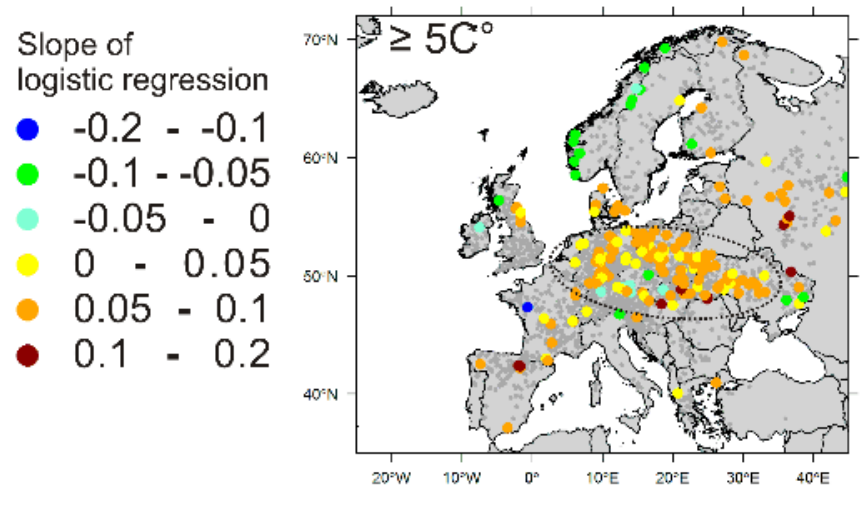

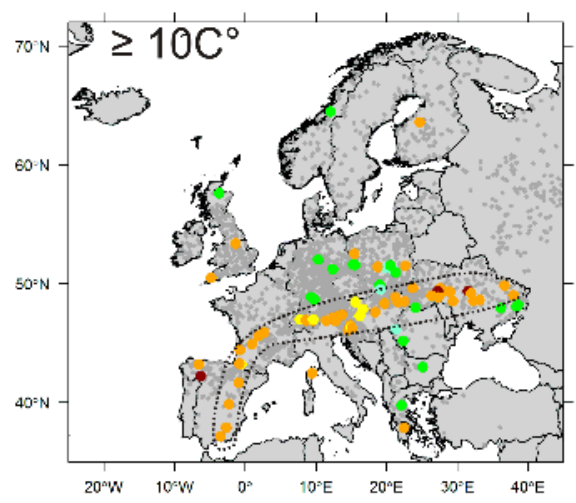

b)

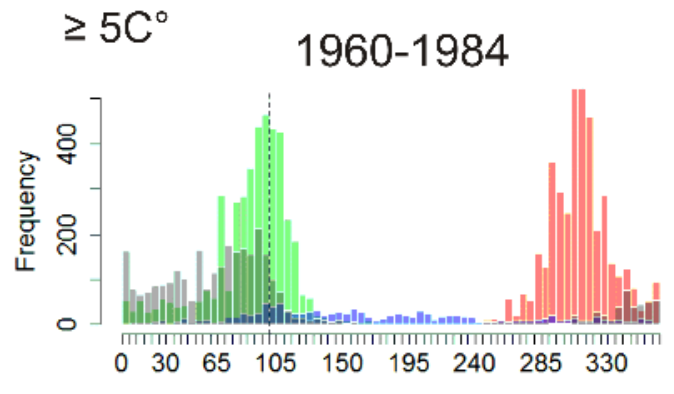

$\geq 5 \mathrm{C}^{\circ}$

$1985-2009$

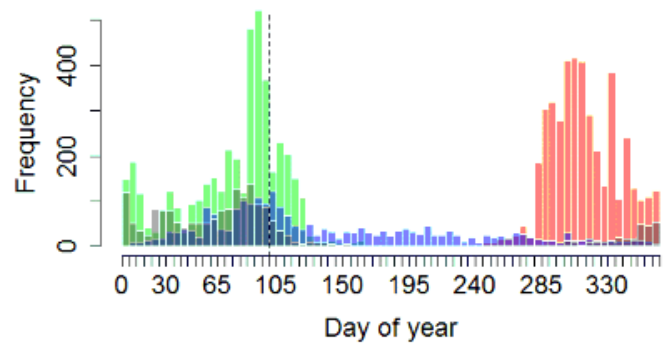

- Start of thermal growing season

- End of thermal growing season

- Flood peak synchrony with growing season

- Flood peak asynchrony with growing season
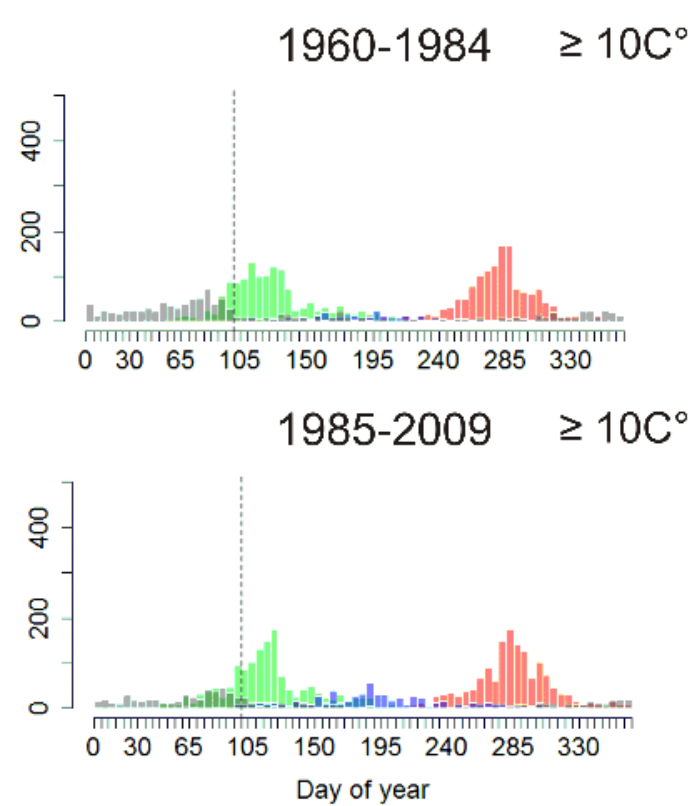

Figure 2. (a) Change in flood-peak occurrence in relation to thermal growing season $\left(\geq 5^{\circ} \mathrm{C}\right.$ and $\geq 10^{\circ} \mathrm{C}$ ). Slope of logistic regression for flood-peak occurrence across years with positive values (warm colors) showing an increasing likelihood in annual flood-peak occurrence within the growing season (i.e., increased synchrony) and negative values (cold colors) a decrease between 1960 and 2010. Only significant trends $(P<0.05)$ are shown $(N=201$ for $\geq 5^{\circ} \mathrm{C}$ and $N=82$ for $\geq 10^{\circ} \mathrm{C}$ ). A cluster of increased synchrony in central/Eastern Europe is indicated by a black circle for the $\geq 5^{\circ} \mathrm{C}$ growing season. Increasing synchrony between flood peaks and the $\geq 10^{\circ} \mathrm{C}$ thermal growing season are observed in a narrow band from Southern Spain towards Eastern Europe. Grey dots indicate time series with more than $80 \%$ available flood data between 1960 and 2009 but no significant trends. (b) Histogram of start and end of the thermal growing season in relation to flood-peak synchrony and asynchrony (i.e., within and outside of the thermal growing season) for two time periods of 25 years each (1960-1984 
and 1985-2009). Only river gauges with significant increase in flood synchrony with the thermal growing season are shown (i.e., stations with positive logistic regression slopes in Figure 2a). The frequency represents the occurrence per river gauge for individual years. A dotted line is drawn at day 100 as reference. Especially for the $\geq 5^{\circ} \mathrm{C}$ thermal growing season, both advancement of spring and a delay in the flood peak timing have led to an increase in flood synchrony with the growing season (blue bars). Within the $\geq 5^{\circ} \mathrm{C}$ growing season flood peak occurrence increased from $26.2 \%$ (1960-1984) to $54.8 \%$ (1985-2009). For the $\geq 10^{\circ} \mathrm{C}$ growing season this increased from $20.2 \%$ to $46.7 \%$ (also see Table S10).

\section{Discussion}

Our study presents evidence of an increasing overlap of the annual river flood peaks, especially with the $\geq 5^{\circ} \mathrm{C}$ thermal growing season in Central and Eastern Europe. Blöschl et al. (2017) already showed the delay of river flood peaks in this area since 1960. Combined with the advancement of spring (Figure 2b) and an overall lengthening of the growing season in the region by 2.5 days/10 years (Wypych et al., 2017) the likelihood for flood-peak occurrences during the growing season has significantly increased (Figure 2a). There is also evidence for increasing synchrony of flooding with the $\geq 10^{\circ} \mathrm{C}$ thermal growing season, however, the spatial clustering of this is less pronounced (Figure 2a). Generally, such

increasing physical-phenological synchrony can only be detected where most flood peaks do not already occur within the growing season and vice versa (see Figure 1) and is dependent on which baseline temperature is assumed for the growing season. For both analyzed thermal growing seasons, where significant synchronization between flood peak and growing season occurred, an increase from less than $20 \%$ to more than $55 \%$ of within growing season floodpeak occurrence was observed (S10).

Advancement of phenological events, such as birch-leaf unfolding in Central and Eastern Europe, has also been evidenced by in-situ phenological observations. The drivers of the observed phenological advancement in Central Europe are thought to be complex and linked to changes of multiple weather oscillation patterns (Aasa et al., 2004). Timing of phenological events is mainly determined by average temperatures preceding the event (e.g., soil temperature for seed germination; Milbau et al., 2009) and can be species specific.

We have used a reductionist approach to highlight physical-phenological synchrony and asynchrony with the annual flood-peak maxima of Blöschl et al. (2017) and a common baseline air temperature above which biological activity is thought to commence (see Methods). Both processes may require further detailing in future studies depending on the phenological event and species in question (e.g., seed germination or leaf unfolding). Yearly flood peaks may differ in magnitude and hence severity in terms of physical disturbance and biogeomorphic impact in the riparian floodplain and not all annual flood peaks may similarly impact the riparian floodplain.

\section{Implications and Conclusion}

The hydraulic, biogeomorphic and ecological effects of synchronous (i.e., within growing season) versus asynchronous (i.e., outside growing season) flood peaks may differ considerably (Figure 3 ) and hence the evidenced synchronization may have consequences for the future functioning of rivers and riparian floodplains. The effects may be most obvious for vegetation establishment on river banks and channel bars as seedling establishment is intrinsically linked to timing of seed germination and flood peaking (Mahoney \& Rood, 1998; Balke et al., 2014). 
Where seeds germinate earlier in spring due to sufficiently warm temperatures subsequent physical flood disturbance within the growing season may prematurely close the 'Window of Opportunity' for seedling establishment and inhibit recruitment (Balke et al., 2014). Winners and losers of physical-phenological synchrony may be determined by more detailed analysis of temperatures required for germination and flood-peak timing within the summer month. General absence of flood peak disturbance during the growing season is likely to benefit seedling survival of all species. Questions also remain about how organisms in floodplains have adapted to timing of flood-peak occurrence and if they will be able to adjust to ongoing rates of change. Seed dormancy is an adaptation to cold winters and drought and tundra willows (Salix spp.) have, for example, adapted dormancy depending on latitudinal distribution of the species (Densmore \& Zasada, 1983).

Altered recruitment of bare sediment by vegetation, macrophyte biomass and presence or absence of deciduous canopies all potentially affect the biophysical interactions of vegetation through flow routing and channel migration (Tal \& Paola, 2007). Moreover, flood-peak timing and magnitude in relation to growing season may also determine which types of particulate and dissolved organic matter are mobilized for example through removal of live vs. dead biomass or established connectivity to backwaters in different seasons (Besemer et al., 2009). Further field studies are required to identify and quantify the effects of increased physical-phenological synchrony in the identified region.

Our findings demonstrate the need to further study the changes and general importance of physical-phenological synchrony/asynchrony in all vegetated ecosystems that closely interact with hydrogeomorphic processes such as mangroves, salt marshes, dunes, sea grass beds, but also vegetated hillslopes and periglacial areas. Shifts in biophysical synchrony/asynchrony may be as important to ecosystem functioning globally as the so far predominantly studied biological match/mismatch processes in a changing climate. 


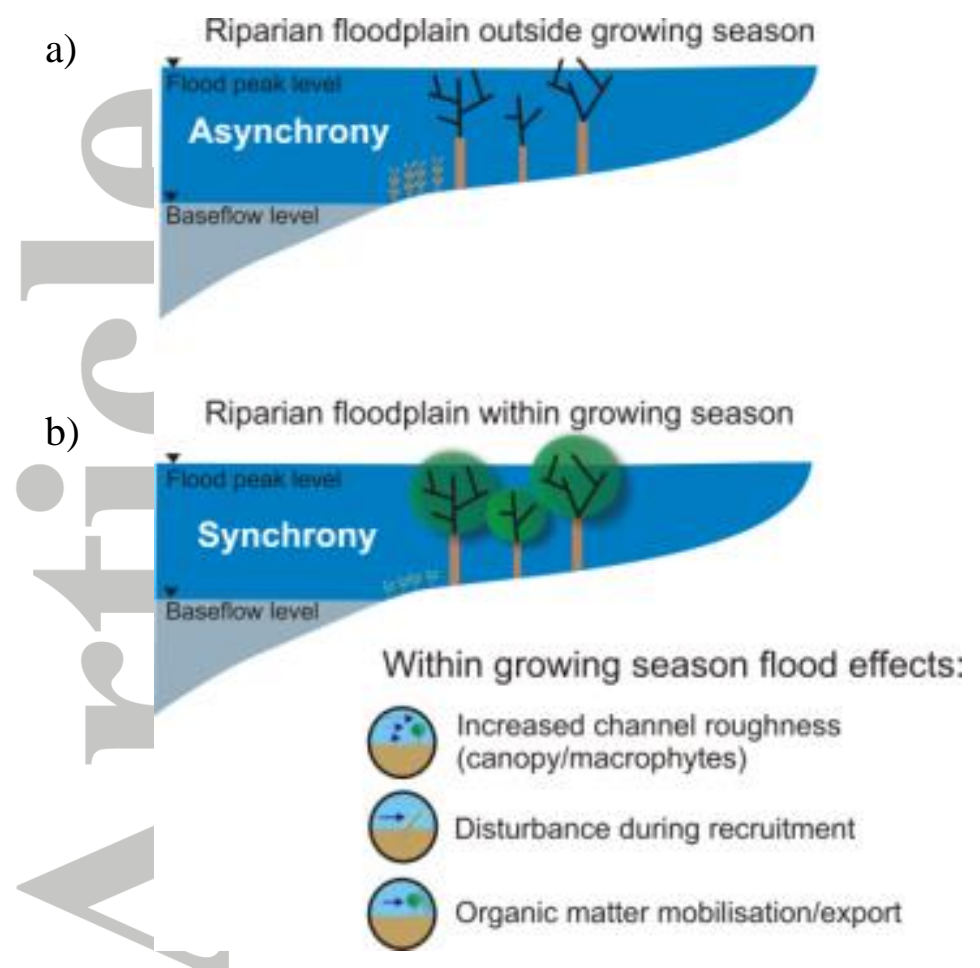

Figure 3. Functional difference of asynchronous and synchronous flood peak and growing season. (a) Annual maximum flood peaks outside the growing season (asynchrony) inundate a largely dormant riparian ecosystem without active seedling recruitment processes and deciduous canopies. (b) During the biologically active growing season (i.e., synchrony) deciduous canopies and macrophytes provide greater hydraulic roughness in the floodplain and channel bars. Depending on the timing of seed germination in relation to flood disturbance seedling establishment may be limited when flood peaks occur within the growing season. High water levels connect backwaters to the river channel and remove plant organic matter from the floodplain and hence the type and quantity of organic matter that is mobilized during flood events are likely to differ between seasons. 


\section{Acknowledgments, Samples, and Data}

We acknowledge the E-OBS dataset from the EU-FP6 project ENSEMBLES (http://ensembles-eu.metoffice.com) and the data providers in the ECA\&D project (http://www.ecad.eu). We thank Susan Waldron and David Merritt for commenting on earlier versions of this manuscript. Balke acknowledges Carnegie Trust Research Incentive Grant RIG007444 and Nilsson acknowledges funding from the Swedish EPA and the Swedish research council Formas.
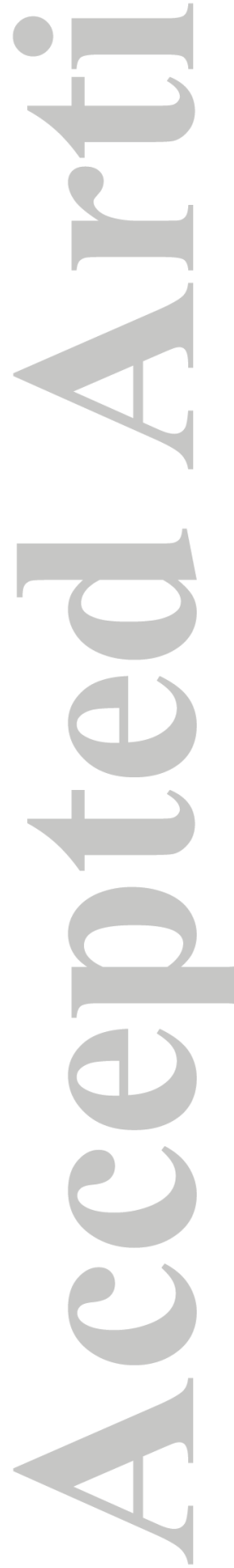


\section{References}

Aasa, A., Jaagus, J., Ahas, R., \& Sepp, M. (2004). The influence of atmospheric circulation on plant phenological phases in central and eastern Europe. International Journal of Climatology, 24, 1551-1564.

Balke, T., Bouma, T., Horstman, E., Webb, E., Erftemeijer, P., \& Herman, P. (2011). Windows of opportunity: thresholds to mangrove seedling establishment on tidal flats. Marine Ecology Progress Series, 440, 1-9.

Balke, T., Herman, P. M. J., \& Bouma, T. J. (2014). Critical transitions in disturbance-driven ecosystems: identifying windows of opportunity for recovery. Journal of Ecology, 102, 700708 .

Barichivich, J., Briffa, K. R., Myneni, R. B., Osborn, T. J., Melvin, T. M., Ciais, P., et al. (2013). Large-scale variations in the vegetation growing season and annual cycle of atmospheric $\mathrm{CO}_{2}$ at high northern latitudes from 1950 to 2011. Global Change Biology, 19, 3167-3183.

Berghuijs, W. R., Allen, S. T., Harrigan, S., \& Kirchner, J. W. (2019). Growing spatial scales of synchronous river flooding in Europe. Geophysical Research Letters, 46, 1423-1428. https://doi.org/10.1029/2018GL081883

Besemer, K., Luef, B., Preiner, S., Eichberger, B., Agis, M., \& Peduzzi, P. (2009). Sources and composition of organic matter for bacterial growth in a large European river floodplain system (Danube, Austria). Organic Geochemistry, 40, 321-331.

Blöschl, G., Hall, J., Parajka, J., Perdigão, R. A. P., Merz, B., Arheimer, B., et al. (2017). Changing climate shifts timing of European floods. Science, 357, 588-590.

Corenblit, D., Baas, A., Balke, T., Bouma, T., Fromard, F., Garófano-Gómez, V., et al. (2015). Biogeomorphic feedbacks along water-terrestrial interfaces. Global Ecology and Biogeography, 24, 1363-1376.

Coomes, O. T., Lapointe, M., Templeton, M., \& List, G. (2016). Amazon river flow regime and flood recessional agriculture: flood stage reversals and risk of annual crop loss. Journal of Hydrology, 539, 214-222.

Cooper, E. J. (2014). Warmer shorter winters disrupt Arctic terrestrial ecosystems. Annual Review of Ecology, Evolution, and Systematics, 45, 271-295.

Cushing, D. H. (1990). Plankton production and year-class strength in fish populations: An update of the match/mismatch hypothesis. Advances in Marine Biology, 26, 250-313.

Densmore, R., \& Zasada, J. (1983). Seed dispersal and dormancy patterns in northern willows: Ecological and evolutionary significance. Canadian Journal of Botany, 61, 32073216.

Department of Energy and Climate Change. (2013). Thermal growing season in central England. https://assets.publishing.service.gov.uk/government/uploads/system/uploads/attachment_data /file/192601/thermal_growing_season_summary_report.pdf 
Donat, M. G., Renggli, D., Wild, S., Alexander, L. V., Leckebusch, G. C., \& Ulbrich, U. (2011). Reanalysis suggests long-term upward trends in European storminess since 1871. Geophysical Research Letters, 38, L14703, doi:10.1029/2011GL047995.

Edwards, M., \& Richardson, A. J. (2004). Impact of climate change on marine pelagic phenology and trophic mismatch. Nature, 430, 881-884.

Friedman, M. F. \& Lee, V. J. (2002) Extreme floods, channel change, and riparian forests along ephemeral streams. Ecological Monographs,72, 409-425.

Haylock, M. R., Hofstra, N., Klein Tank, A. M. G., Klok, E. J., Jones, P. D., \& New, M. (2008). A European daily high-resolution gridded data set of surface temperature and precipitation for 1950-2006. Journal of Geophysical Research, 113, D20119, doi:10.1029/2008JD010201.

Inouye, D. W. (2008). Effects of climate change on phenology, frost damage, and floral abundance of montane wildflowers. Ecology, 89, 353-362.

Isaac, V. J., Castello, L., Santos, P. R. B., \& Ruffino, M. L. (2016). Seasonal and interannual dynamics of river-floodplain multispecies fisheries in relation to flood pulses in the Lower Amazon. Fisheries Research, 183, 352-359.

Jentsch, A., Kreyling, J., Boettcher-Treschkow, J., \& Beierkuhnlein, C. (2009). Beyond gradual warming: extreme weather events alter flower phenology of European grassland and heath species. Global Change Biology, 15, 837-849.

Jeong, S.-J., Ho, C.-H., Gim, H.-J., \& Brown, M. E. (2011). Phenology shifts at start vs. end of growing season in temperate vegetation over the Northern Hemisphere for the period 1982-2008. Global Change Biology, 17, 2385-2399.

King, A. J., Humphries, P., \& Lake, P. S. (2003). Fish recruitment on floodplains: The roles of patterns of flooding and life history characteristics. Canadian Journal of Fisheries and Aquatic Sciences, 60, 773-786.

Kopp, R. F., Abrahamson, L. P., White, E. H., Volk, T. A., Nowak, C. A., \& Fillhart, R. C. (2001). Willow biomass production during ten successive annual harvests. Biomass and Bioenergy, 20, 1-7.

Kovats, R. S., Valentini, R., Bouwer, L. M., Georgopoulou, E., Jacob, D., Martin, E., et al. (2014). Europe, in Climate change 2014: Impacts, adaptation, and vulnerability. Part B: Regional aspects. Contribution of Working Group II to the Fifth Assessment Report of the Intergovernmental Panel of Climate Change, edited by: Barros, V. R., Field, C. B., Dokken, D. J., Mastrandrea, M. D., Mach, K. J., Bilir, T. E., et al., pp. 1267-1326.

Leblond, M., St-Laurent, M.-H., \& Côté, S. D. (2016). Caribou, water, and ice: Fine-scale movements of a migratory arctic ungulate in the context of climate change. Movement Ecology, 4:14. DOI 10.1186/s40462-016-0079-4.

Mahoney, J. M., \& Rood, S. B. (1998). Streamflow requirements for cottonwood seedling recruitment - an integrative model. Wetlands, 18, 634-645. 
Mainwaring, M. C., Barber, I., Deeming, D. C., Pike, D. A., Roznik, E. A., \& Hartley, I. R. (2017). Climate change and nesting behaviour in vertebrates: a review of the ecological threats and potential for adaptive responses: Climate change and nesting behaviour.

Biological Reviews, 92, 1991-2002.

McClure, O. (2016). Flooding damage to agriculture now estimated at \$277 million. LSU

College of Agriculture.

http://www.lsuagcenter.com/profiles/rbogren/articles/page1473790249567

Menzel, A. (2000). Trends in phenological phases in Europe between 1951 and 1996.

International Journal of Biometeorology, 44, 76-81.

Milbau, A., Graae, B.J., Shevtsova, A., \& Nijs, I. (2009). Effects of a warmer climate on seed germination in the subarctic. Annals of Botany, 104, 287-296.

Miller, T. E., Gornish, E. S., \& Buckley, H. L. (2010). Climate and coastal dune vegetation: disturbance, recovery, and succession. Plant Ecology, 206, 97-104.

Möller, I., Kudella, M., Rupprecht, F., Spencer, T., Paul, M., van Wesenbeeck, B. K., et al. (2014). Wave attenuation over coastal salt marshes under storm surge conditions. Nature Geoscience, 7, 727-731.

Nilsson, C., Brown, R. L., Jansson, R, \& Merritt, D. M. (2010). The role of hydrochory in structuring riparian and wetland vegetation. Biological Reviews, 85, 837-858.

Parmesan, C., \& Yohe, G. (2003). A globally coherent fingerprint of climate change impacts across natural systems. Nature, 421, 37-42.

Perucca, E., Camporeale, C., \& Ridolfi, L. (2007). Significance of the riparian vegetation dynamics on meandering river morphodynamics, Water Resources Research, 43, W03430.

Pusey, B. J., \& Arthington, A. H. (2003). Importance of the riparian zone to the conservation and management of freshwater fish: a review. Marine and Freshwater Research, 54, 1-16.

Royan, A., Hannah, D. M., Reynolds, S. J., Noble, D. G., \& Sadler, J. P. (2013). Avian community responses to variability in river hydrology. PLOS ONE, 8, e83221.

Ruosteenoja, K., Räisänen, J., Venäläinena, A., \& Kämäräinena, M. (2016). Projections for the duration and degree days of the thermal growing season in Europe derived from CMIP5 model output. International Journal of Climatology, 36, 3039-3055.

Sang, R., Lutomiah, J., Said, M., Makio, A., Koka, H., Koskei, E., et al. (2017). Effects of irrigation and rainfall on the population dynamics of rift valley fever and other arbovirus mosquito vectors in the epidemic-prone Tana River County, Kenya. Journal of Medical Entomology, 54, 460-470.

Seddon, A. W. R., Macias-Fauria, M., Long, P. R., Benz, D., \& Willis, K. J. (2016).

Sensitivity of global terrestrial ecosystems to climate variability. Nature, 531, 229-232.

Spencer, D. F., \& Ksander, G. G., (2006) Estimating Arundo donax ramet recruitment using degree-day-based equations. Aquatic Botany, 85, 282-288. 
Stevenson, T. J., Visser, M. E., Arnold, W., Barrett, P., Biello, S., Dawson, A., et al. (2015). Disrupted seasonal biology impacts health, food security and ecosystems. Proceedings of the Royal Society B - Biological Sciences, 282, 20151453, DOI: 10.1098/rspb.2015.1453.

Tal, M., \& Paola, C. (2007). Dynamic single-thread channels maintained by the interaction of flow and vegetation. Geology, 35, 347-350.

Thackeray, S. J., Henrys, P. A., Hemming, D., Bell, J. R., Botham, M. S., Burthe, S., et al. (2016). Phenological sensitivity to climate across taxa and trophic levels. Nature, 535, 241245.

Visser, M. E., \& Gienapp, P. (2019). Evolutionary and demographic consequences of phenological mismatches. Nature Ecology \& Evolution. DOI:10.1038/s41559-019-0880-8.

Woodward, G., Bonada, N., Brown, L. E., Death, R. G., Durance, I., Gray, C., et al. (2016). The effects of climatic fluctuations and extreme events on running water ecosystems. Philosophical Transactions of the Royal Society B: Biological Sciences, 371, 20150274.

Wypych, A., Sulikowska, A., Ustrnul, Z., \& Czekierda, D. (2017) Variability of growing degree days in Poland in response to ongoing climate changes in Europe. International Journal of Biometeorology, 61, 49-59.

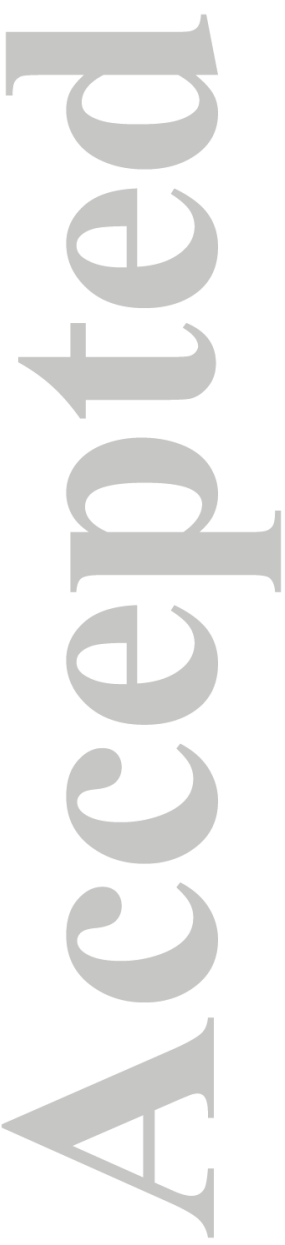

